UDC 658

DOI: $10.31891 / 2307-5740-2020-288-6-45$

ZAITSEV YURII, KHAOLIN LIU

Kharkiv Petro Vasylenko National Technical University of Agriculture

\title{
MODERN DIRECTIONS OF ENSURING THE COMPETITIVENESS OF AGRICULTURAL PRODUCTS OF UKRAINE
}

Competitiveness should be understood as the ability of an individual entity to function successfully in a competitive environment, having an absolute or relative advantage over the "main players" - key competitors in the market. It is determined that the competitiveness of products is associated with the appropriate level of its quality, which is better than analogues to meet the needs of consumers. Another component is the cost of products, the nature of which is more variable compared to quality, which explains the formation of quality throughout the production cycle under the influence of mostly objective factors. The cost of production, which consists of cost and profit, has a higher level of variability due to the dependence of the level of profit on the state of market demand. In terms of profit, the competitiveness of products is closely linked to the success of the enterprise, its stability and development potential. Another aspect of product competitiveness is considered market parameters. Thus, "hard" and "soft" factors of product competitiveness were distinguished, where the first group is represented by the quality and cost of production, and the second - profit and marketing. The analysis of the existing criteria of competitiveness of goods allowed to add to the identified factors the following: social targeting, consumer novelty, informativeness, reliability, safety for consumers and the environment, product image. Features of ensuring the competitiveness of products in the agricultural sector are considered. The dependence of agricultural specialization on the location determines the critical dependence of product quality on the resource potential, which requires preservation and reproduction. This necessitates the inclusion of environmentally responsible components of responsible land use in the ways of ensuring the competitiveness of products. It is determined that the most difficult factor in managing the competitiveness of agricultural products is the price due to the peak load in the collection of crops and the need for significant storage reserves for storage of products for a long time. Ways to manage this factor are proposed to consider the development of commodity exchanges, the use of financial instruments, risk insurance. Horizontal integration for small farms and vertical integration for agricultural enterprises are recognized as additional ways to ensure the competitiveness of agricultural products.

Keywords: competitiveness, product competitiveness, agricultural enterprises, agricultural products, quality, cost, price.

ЗАЙЦЕВ Ю. О., ЛЮ ХАОЛІНЬ

Харківського національного технічного університету сільського господарства імені Петра Василенка

\section{СУЧАСНІ НАПРЯМКИ ЗАБЕЗПЕЧЕННЯ КОНКУРЕНТОСПРОМОЖНОСТІ АГРАРНОЇ ПРОДУКЦІї УКРАЇНИ}

Під конкурентоспроможністю варто розуміти здатність окремого суб'єкта успішно функціонувати в умовах конкуренції, маючи абсолютну або відносну перевагу над «основними гравцями» - ключовими конкурентами на ринку. Визначено, що конкурентоспроможність продукції пов'язана із відповідним рівнем ії якості, здатної краще за аналоги задовольняти потреби споживачів.

Іншим компонентом виступає вартість продукції, природа якої у порівнянні з якістю є більш варіативною, що пояснюється формування якості впродовж вСього виробничого циклу під впливом переважно об'єктивних чинників. Вартість продукції, яка складається із собівартості й прибутку, відрізняється вищим рівнем варіативності через залежність рівня прибутку від стану попиту на ринку. В аспекті прибутку конкурентоспроможність продукції тісно пов'язана із успішністю функціонування підприємства, його стабільністю й можливістю розвитку.

Ще одним аспектом конкурентоспроможності продукції розглянуто ринкові параметри. Таким чином було виокремлено «жорсткі» й «м'які» чинники конкурентоспроможності продукції, де перша група представлена якістю собівартістю продукцію, а друга - прибутком і комплексом маркетингу. Аналіз існуючих критеріїв конкурентоспроможності товарів дозволив до визначених чинників додати такі: соціальна адресність, споживча новизна, інформативність, достовірність, безпека для споживачів і оточення, імідж товару.

Розглянуто особливості забезпечення конкурентоспроможності продукції в аграрному секторі. Залежність спеціалізації сільського господарства від території розміщення обумовлює критичну залежність якості продукції від ресурсного потенціалу, який вимагає збереження й відтворення.

Це обумовлює необхідність включення до шляхів забезпечення конкурентоспроможності продукції екологічних компонентів відповідального землекористування. Визначено, що найскладнішим чинником в управлінні конкурентоспроможністю аграрної продукції виступає ціновий через пікове навантаження у зборі сільськогосподарських культур і необхідність значних резервів складування для зберігання продукції на протязі тривалого часу. Шляхами управління цим чинником запропоновано розглядати розвиток товарних бірж, використання фінансових інструментів, страхування ризиків. Додатковими шляхами забезпечення конкурентоспроможності аграрної продукції визнано горизонтальну інтеграція для мілких господарств населення й вертикальну для сільськогосподарських підприємств.

Ключові слова: конкурентоспроможність, конкурентоспроможність продукції, сільськогосподарські підприємства, аграрна продукція, якість, вартість, ціна.

The need to compete successfully in domestic and foreign markets requires special attention to the concept of competitiveness, which in fact embodies the quintessence of most scientific and theoretical research, methodological developments, practical provisions and applied recommendations to ensure the success of the business entity in today's economic space, as an enterprise remains the main producer of products, works and services that meet the needs of the population, while providing expanded reproduction. An enterprise in a market 
economy cannot function effectively, develop stably and implement the functions of corporate social responsibility in the case of low competitiveness of its own products and the enterprise as a whole. In addition, this concept is considered at all levels: global, national, regional. There is the competitiveness of the country, industry, region and most importantly - the company. The company itself, producing products for the market, is the basis of all other types of competitiveness at all levels. Thus, the study of aspects of enterprise competitiveness is associated with almost all other aspects of economic activity of economic entities. Product competitiveness plays a special role in ensuring the competitiveness of the enterprise, acting as its basis, base and at the same time the result, which greatly complicates the search for causal links, the determination and management of which is the basis of scientific research. All of the above determines and confirms the relevance of the study.

Competitiveness as an object of study has been considered by a significant number of domestic and foreign researchers.

Among foreign scientists such as H.L. Azoiev, M. Porter, W. Liefert, J. Schumpeter, R.A. Fatkhutdinov, A.Yu. Yudanov and others.

L. Ye. Dovhan, O. I. Drahan, L. I. Piddubna, O. H. Yankovyy dealt with the issues of product competitiveness analysis. Aspects of competitiveness of products of agricultural enterprises are considered in the works of V.Ya. Ambrosov, V.H. Andriichuk, O.D. Hudzynskii, S.I. Demianenko, O.Yu. Yermakov, V.V. Zinovchuk, S.M. Kvasha, P.M. Makarenko, M.Y. Malik, V.Ya. Mesel-Veseliak, P.T. Sabluk, I.N. Topikha, I.I. Cherven, V.V. Yurchyshyn, V.M. Yatsenko. Despite numerous scientific developments, the issue of finding new ways to ensure the competitiveness of agricultural products requires further development and in-depth analysis.

\section{The aim of the study}

The purpose of the study is to determine modern areas of ensuring the competitiveness of agricultural products in Ukraine.

\section{Presentation of the main research material}

The development of the concept of "competitiveness" is inextricably linked with the evolution of research on the phenomenon of competition in economics. It is obvious to consider it as a derivative of competition. Despite the close connection between these concepts, their subject areas differ significantly. During the development of economics, competitiveness was separated as a separate area in the 20 s of the twentieth century.

In economics, the concept of "competitiveness" was introduced by M. Porter, defining it as the property of a good, service or business entity to function in the market and position its products together with analogues offered by major competitors [1]. A well-known Russian economist also considered it as a property of an object, which is characterized by the degree of actual or potential satisfaction of competitive needs in comparison with analogues, as the ability to compete with similar objects on the market [2]. A more broad definition is found in [3], where it is defined as an indicator of the ability to supply goods and services in the place, in the form and at the time when they are needed by buyers, at a price not worse or better than potential competitors, in while revenues at least correspond to the opportunity cost of resources used in the production process.

In general, competitiveness should be understood as the ability of an individual to operate successfully in a competitive environment, having an absolute or relative advantage over the «main players». Depending on the subject, competitiveness differs in its features and properties. For the company - it is an advantage in the struggle in certain markets, for the region - it is preferences within the state along with other regions, for the national economy it is a global ability to effectively position itself in the foreign market. At the heart of all these types is the competitiveness of products.

Despite the similarity of the concepts of «enterprise competitiveness» and «product competitiveness» and their close connection between them, there are many differences.

M. Halvanovskyy and others [4] define it as the ratio of price and quality of specific goods produced by individual enterprises and firms, or services provided by them. V. Vasylkov [5] provides a more capacious definition: as a level of competence in relation to competitors in the accumulation and use of production potential of a particular direction, as well as its components, represented by technology, resources and management, skills and knowledge embodied in product quality, profitability and productivity. Another approach is proposed by G. Kindratska, who defines it as the ability to operate efficiently and ensure profitability in a competitive market, as a result of the functioning of a competitive enterprise [6].

A rather capacious definition is presented in the work of S. Klymenko and others [7], where it is noted that the competitiveness of products combines its properties to meet a specific need in comparison with analogues in the market; the set of characteristics of goods that distinguish them from the products of competitors in the degree of compliance with social needs and costs for its satisfaction; situational factor of the product's ability to meet market requirements; ability to withstand competition in general (the presence of competitive advantages).

All other definitions to a greater or lesser extent reflect these aspects of product competitiveness. This allows you to make some generalizations. First of all, the competitiveness of a product is related to the appropriate level of its quality, which is better than similar products on the market to meet existing or future needs. This corresponds to its basic component, which is represented by quality. Quality itself is a set of properties of any object that reflects its nature, purpose, structure, character, and so on. Regarding product quality, we are talking about a set of properties that can meet individual needs. This concept is absolute. In contrast, competitiveness is a relative 
property of a particular product to meet certain needs better than competitors. Another component of product competitiveness is cost - the price of products. This category is also absolute, but unlike quality, its nature is more variable. That is, the appropriate level of product quality is formed as a result of the enterprise during the production cycle depending on many technical, organizational, managerial, resource parameters that can be combined within the concept of «enterprise potential» under the influence of many external factors. Given the high level of complexity of the systems that determine the level of product competitiveness, ensuring the desired result at the output requires careful management of input processes and during the production cycle. This category is the most objective in terms of product competitiveness, which makes it impossible to make changes to the end result in the absence of appropriate changes in the process. The nature of the price is significantly different, as it consists of cost and profit. Cost is also a fairly objective characteristic, but given the numerical methods of its calculation, there are some possibilities to make adjustments to the resulting object depending on the purpose. The most variable and accordingly important, from the point of view of management, component is profit. Its level objectively depends on the average industry level, and the volume should provide expanded reproduction and development of the enterprise. Profit, in contrast to cost and quality, strongly depends on market parameters: its volume, size of individual segments, the nature of competition in the market (monopolistic competition, monopoly, monopsony, oligopoly, etc.), numerous situational factors, general socio-economic situation and more. All these factors have a greater or lesser impact on the pricing process, but the level of effective demand and the balance between supply and demand for an acceptable price level remains key. It is in the aspect of profit that the competitiveness of products is closely interrelated with the success of the enterprise, its stability and the possibility of development.

Another important external component of product competitiveness are market parameters. This largely reflects the comparative characteristics of the studied feature: in a particular market, consumers choose the best product, thus forming the market structure. Consumer commitment depends not only on the quality and price of products, but also on the implementation of a set of marketing measures for product positioning, support, advertising and more. The influence of these parameters significantly depends on the nature of the market.

The authors emphasize the qualitative and quantitative aspects of competitiveness [8, 9]. The qualitative side reflects the confrontation of competitors with the appropriate balance between supply and demand, which requires analysis of the market, its trends and relationships. The promotion of goods on the market is associated with the so-called «transaction costs» of information retrieval, verification of counterparties, determination in the system of activities in the economic system of coordinates of the industry, region, country. In this aspect, the economic survival of the entity depends on the competitiveness of the product.

This allows you to consider the «hard» and «soft» factors of product competitiveness. The quality and cost of production should be considered rigid. As the experience of leading countries and powerful Western corporations shows, the introduction of modern innovative technologies can not only significantly reduce the unit cost of production, which can increase productivity and significantly reduce costs, but also improve the quality of finished products. That is, these parameters are actually interdependent - the improvement of the production process has a positive effect on the effectiveness of the enterprise as a whole. On the other hand, aspects of the impact of direct costs on product competitiveness remain unchanged: the use of more costly materials, raw materials and semifinished products increases the cost of production, where savings at full cost are possible only in the case of «scale effect». Also, investments in fixed assets in the form of the purchase of new equipment, the introduction of innovative technologies, the purchase of costly equipment lead to a significant increase in depreciation, which is a significant part of the cost of production. In any case, the introduction of innovative technologies allows to ensure a long-term positive result in the context of saving current costs, ensuring a stable increase in product quality.

The «soft» aspects of product competitiveness include profit and marketing. Their nature largely depends on situational factors: the company can adjust the price depending on the current level of demand, manage sales, using storage resources, marketing tools and logistics capacity.

All considered components act as determinants or initial parameters on which the level of competitiveness of production of the enterprise depends.

The most common parameters of product competitiveness are the following [10]: technical, which combine ergonomic, aesthetic and purpose parameters (classification, technical efficiency and design); economic include onetime and current; regulations combine the parameters of safety, patent purity and environmental friendliness.

In addition to these parameters, researchers [11, 12] propose criteria for the competitiveness of goods, which include quality; social targeting as the conformity of product characteristics to the specific needs of a social group of consumers or a specific buyer; consumer novelty of the product as a manifestation of the novelty of the consumer properties of a particular product in comparison with the previous version or with competitors; informativeness as the ability to show their social value through information about competitive advantages; consumption price; reliability as a reflection of product protection; safety for life, health, property of the consumer and the environment, safety of work performance; product image.

Regarding the products of the agricultural sector, the key should be considered quality, for certain groups of products, social targeting, informativeness of the product, and special attention should be paid to safety. This aspect of competitiveness has recently become increasingly important due to the development of organic farming, which allows to grow environmentally friendly agricultural products. In addition, land exploitation threatens their 
future fertility, which, along with consumer safety, requires attention to environmental safety.

Agricultural products, unlike other industries, have a number of unique properties that determine the ways to ensure its competitiveness. This is due to the action of many factors, among which special attention should be paid to the resource component.

The domestic branch of agriculture is represented mainly by crop production with a stable gradual decline of animal husbandry. The quality of crop production significantly depends on the condition of soils, crop production technologies, the nature of crop rotation, the level of renewal of varieties, the amount of mineral and organic fertilizers and more. Technical parameters to a greater extent affect productivity, which determines the level of efficiency of the enterprise, and the amount of product losses, which is reflected in its cost. An important factor is the direct dependence of the specialization of agriculture, especially crop production, on the location. This causes no alternative in the choice of crop types and methods of cultivation. This interdependence requires increased attention to the preservation of resource potential. In the case of irresponsible use of fertile chernozems to obtain high yields without proper reproduction of soil productivity, which has recently become a traditional phenomenon, the level of their effectiveness will decline rapidly, jeopardizing the functioning of the enterprise as a whole. This aspect requires the inclusion of environmentally responsible components of responsible land use in the ways of ensuring the competitiveness of products. A similar situation has developed with regard to labor resources, which due to the unsatisfactory level of social infrastructure in rural areas and relatively low wages are not interested in living in rural areas. Unlike other sectors of the economy, labor resources in the agricultural sector have a very low level of mobility, which necessitates the need to take into account the social security factor and the level of infrastructure development to provide highly qualified agricultural enterprises.

Thus, agricultural enterprises in developing ways to ensure the appropriate level of product competitiveness in terms of resource management should focus not only on economic parameters but also social and environmental, which allows us to consider sustainable development as the only possible for the domestic agricultural sector.

The development of resource potential and its comprehensive reproduction will ensure the appropriate level of product quality, creating the main basis for competitiveness.

The most difficult issue in managing the competitiveness of agricultural products is the price factor, which is due to the peak load in the collection of individual crops and, accordingly, significant fluctuations in food prices. In addition, the lack of sufficient reserves for storage and the short shelf life of certain types of agricultural products contributes to the desire of individual producers to sell products as soon as possible, given the significant length of the production cycle. A powerful lever in this situation is the state, which is able to implement public procurement policy to support domestic producers. Another tool for hedging price risks can be considered commodity exchanges, which allow using a variety of financial instruments to plan business results, insuring risks.

Significant global agricultural market, strong integration between economies, extensive trade and economic ties contribute to significant price fluctuations due to significant differences in yields of individual crops in different countries, due to the level of favorable natural and climatic parameters of specific areas per year. All this puts domestic producers in fact directly dependent on the level of world prices for certain crops, which directly affects the level of competitiveness of products.

In the domestic market, most of the products of farmers are used in processing, which requires the construction of close cooperation to ensure the appropriate level of quality of raw materials, which will affect the quality and competitiveness of enterprises in the derived industries. In this context, consideration should be given to considering integration vertical links that allow for significant cost savings through the introduction of transfer pricing. Horizontal cooperation allows to unite individual farms in order to improve the quality of their products, the introduction of quality management standards, the purchase of modern equipment to replace manual labor, which will significantly affect the level of productivity. For Ukrainian farmers, where the lion's share of production is still produced by the economy, this issue is particularly relevant. In addition, without proper measures to ensure product quality and standardization, the integration of Ukrainian agriculture into the European community is virtually impossible. It is because of the inconsistency of quality that Ukrainian agricultural products are very limited in the world market. Unfortunately, those products that do not have a high level of added value are in demand.

\section{Conclusions and prospects for further research}

Based on the study, a number of conclusions should be drawn.

Competitiveness is the ability of an individual to operate successfully in a competitive environment, having an absolute or relative advantage over the «main players» - key competitors in the market. Product competitiveness is associated with an appropriate level of quality that can better meet the needs of consumers than analogues. Another component is the cost of products, the nature of which is more variable compared to quality, which is explained by the formation of quality throughout the production cycle under the influence of mostly objective factors. The cost of production, which consists of cost and profit, has a higher level of variability due to the dependence of the level of profit on the state of market demand. In terms of profit, the competitiveness of products is closely linked to the success of the enterprise, its stability and development potential. Another aspect of product competitiveness is considered market parameters. Thus, "hard" and "soft" factors of product competitiveness were distinguished, where the first group is represented by the quality and cost of production, and the second - profit and marketing. Analysis of the existing criteria of competitiveness of goods allowed to add to the identified factors the 
following: social targeting, consumer novelty, informativeness, reliability, safety for consumers and the environment, the image of the product.

Features of ensuring the competitiveness of products in the agricultural sector are considered. The dependence of agricultural specialization on the location determines the critical dependence of product quality on the resource potential, which requires preservation and reproduction. This necessitates the inclusion of environmentally responsible components of responsible land use in the ways of ensuring the competitiveness of products. Peculiarities of providing skilled labor resources of agricultural enterprises determine the need to take into account social aspects in terms of factors ensuring the competitiveness of agricultural products.

It is determined that the most difficult factor in managing the competitiveness of agricultural products is the price due to the peak load in the collection of crops and the need for significant storage reserves for storage of products for a long time. Another aspect is the inability to store in its original form certain crops, which requires rapid implementation and significantly affects the price level and, accordingly, competitiveness. Ways to manage this factor are proposed to consider the development of commodity exchanges, the use of financial instruments, risk insurance. Horizontal integration for small farms and vertical integration for agricultural enterprises are recognized as additional ways to ensure the competitiveness of agricultural products.

Further research of the author will be devoted to the substantiation of ways to increase the level of competitiveness of agricultural products.

\section{References}

1. Porter, M. (2001). Konkurencija. [Competition]. Vil'jams. Moscow. Russia.

2. Fathutdinov, R.A. (2000). Konkurentosposobnost': jekonomika, strategija, upravlenie. [Competitiveness: economics, strategy, management]. INFRA-M. Moscow. Russia.

3. Duscussion. Paper. No. 2.

4. Gal'vanovskij, M., Zhukovskaja, V., Trofimova, I. (1998). «Competitiveness in micro-, meso- and macro-level dimensions». Rossijskij jekonomicheskij zhurnal. № 3, pp. 67-77.

5. Vasyl'kov, V. (2003). Orhanizatsiia vyrobnytstva. [Organization of production]. KNEU. Kyiv. Ukraine.

6. Kindrats'ka, H.I. (2006). Stratehichnyj menedzhment. [Strategic management]. Znannia. Kyiv. Ukraine.

7. Klymenko, S. M., Omel'ianenko, T. V., Barabas', D. O. ta in. (2008). Upravlinnia konkurentospromozhnistiu pidpryiemstva. [Enterprise competitiveness management]. KNEU. Kyiv. Ukraine.

8. Kuleshova, H. M. (2008). «Competition and competitiveness in agro-industrial production». Ekonomika APK. № 3, pp. 126-132.

9. Burlaka, O. P., Burlaka, O. A. (2012). «Factors of formation of competitiveness of products of agricultural enterprises». Tekhnolohichnyj audyt ta rezervy vyrobnytstva. № 2, pp. 23-26. pp. 66-71.

10. Zheludenko, K. V. (2017). «The essence and factors of competitiveness of products of Ukrainian enterprises». Intelekt XXI. №. 1,

11. Zarits'ka, N. M. (2015). Otsinka konkurentospromozhnosti produktsii pidpryiemstva. [Assessment of the competitiveness of enterprise products]. Efekty`vna ekonomika. [Effective economy]. (electronic journal). № 12. Available at: http://www.economy.nayka.com.ua/?op=1\&z=4647

12. Lifyts', I.M. (2009). Konkurentospromozhnist' tovariv i posluh. [Competitiveness of goods and services]. 2nd ed., Vyscha osvita; Yurajt-Yzdat. Moscow. Russia. 